\title{
Impact of GSCM Practices on Financial Performance: Special Reference to Manufacturing Companies in Sri Lanka
}

\author{
Jayarathna B.C.P. ${ }^{1}$ and Lasantha S.A.R. ${ }^{2}$ \\ Department of Commerce \& Financial Management \\ Faculty of Commerce \& Management Studies, University of Kelaniya \\ ${ }^{1}$ chamari@kln.ac.lk, ${ }^{2}$ sarlasantha@gmail.com
}

\begin{abstract}
Within the context of Green Supply Chain Management (GSCM), firms are currently considering green supply chain practices as a concern not only for environment performance but also financial performance. Therefore this study aims to investigate the impact of GSCM practices on financial performance relating to manufacturing companies in Sri Lanka. For this purpose structured questionnaire was used to collect data from 25 manufacturing companies listed on Colombo Stock Exchange, Sri Lanka. Data were analyzed using Partial Least Square Structural Equation Modeling method. Green supply chain practices were categorized in to four basic practices as internal environmental management, green purchasing, customer cooperation with environmental considerations and eco design, and investment recovery. Financial performance was measured by using Return on Equity. The results showed that green purchasing and investment recovery significantly influence on financial performance and the other two green supply management practices do not significantly affect financial performance.
\end{abstract}

Keywords: Green Supply Chain Management, Financial Performance, Partial Least Square Structural Equation Modeling

\section{Introduction}

The need for environmental research in the business world has been growingly addressed by the researchers in different context including developed and developing countries. Within the domain of environmental research, the concepts of Green Supply Chain Management (GSCM), and Green Supply Chain Practices (GSCP) are taken greater attention for researching as one of the newest areas in supply chain evolution. It is been emerged due to not only increasing social demand for environmental sustainability but also increasing market complexity and

\footnotetext{
${ }^{2}$ http://orcid.org/0000-0003-4525-2693
} 
competitive pressures. Thus firms are currently considering green supply chain practices as a concern for environment sustainability as well as firm's sustainability.

Environmental performance is one of the determinants for environmental sustainability and Economic performance is one of the determinants for firm's sustainability. Balancing between economic performance \& environmental performance has become increasingly important for organizations for facing competitive, regulatory, and community pressures (Shultz \& Holbrook, 1999). With these increasing pressures, firms have to adopt certain strategies, practices and processes to face competition. As a prerequisite for achieving competitiveness, organizations must have some kind of performance measurement (Shi, Koh, Baldwin \& Cucchiella, 2012). Slack, Jones, Johnston and Betts (2012) define performance measurement is "the process of quantifying action, where management means the process of quantification and the performance of the operation is assumed to derive from actions taken by its management". Thus performance may have an influence for the management whether to take some actions or adopt certain practices.

In another aspects organizations are considering that adopting GSCP are worth for the effort of the organizations in terms of environmental, market and financial performance and customer satisfaction (Rahman, Ho \& Rusli, 2014). Therefore within the context of green supply chain management, researches can be executed to find out the relationship between green supply chain practices and company's performance. Though there is an argument that GSCM performance cannot just be based on its financial aspect, this paper investigates the relationship between GSCP and financial performance while controlling performance of operational and environmental aspects to find out whether there is an impact of GSCP on financial performance.

\section{Literature Review}

\section{Green Supply Chain Management}

Zhu and Sarkis (2004) defined green supply chain management within the range from green purchasing to integrated green supply chains from supplier to manufacturer to customer. Srivastava (2007) defined that "GSCM is Integrating environment thinking into supply chain management including product design, material sourcing and selection, manufacturing process, delivery of the final product to the consumer, and end-of-life management if the product after its useful time" (p.54). Typically GSCM includes implementing environmental initiatives in 
different phases in supply chain as inbound logistics, production or internal supply chain, outbound logistics, and reverse logistics. As Most of the literature consider environmental impact of general supply chain practices, Green supply chain management involves environmental concerns for traditional supply chain management (Gilbert, 2000). Several studies have examined the green supply chain management with in different components as green purchasing, green design, green manufacturing and mixture of these components (Bowen, Cousins, Lamming \& Farukt, 2001). Narasimhan and Carter (1998) considered GSCM as advanced management practices for manufacturers to improve their environmental performance. By looking at existing interpretations green supply chain focuses on environmental performance along the supply chain.

\section{Green Supply Chain Practices}

Different studies used different practices for GSCP based on their research scope and GSCM definition. Accordingly, Srivastava (2007) used green design, green operations, reverse logistics, waste management and green manufacturing as GSCP while Lakshmimeera and Palanisamy (2013) categorized green supply chain practices in to inbound practices, operations practices, outbound practices, reverse logistics, management support, and customer support. Chang, Kenzhekhanuly and Park (2013) mentioned practices of green design, green purchasing, green logistics, green packaging as GSCPs. However studies carried out by Zhu and Sarkis (2004, 2007) and Zhu, Geng, Fujita and Hashimoto (2010) categorized GSCP as internal environmental management (IEM), green purchasing(GP), customer cooperation with environmental considerations \& eco design(CC), and investment recovery(IR).

\section{Financial Performance}

Historically Firm's performance were measured using different financial measures such as return on sales (ROS), return on equity (ROE), return on assets (ROA), and return on invested capital (ROIC) by many authors (Hart \& Ahuja, 1996; Hiroki \& Keisuke, 2010; Klingenberg $\&$ Geurts, 2009; Sarkis \& Cordeiro, 2001).Considering the firm's performance relative to the market and it's competition, Debt ratio (DR), profit margin (PM), return on total assets (ROA), and market to book ratio (MBR) are recognized as important dimensions to firm's financial performance (Slywotzky et al., 2000; Ngniatedema \& Li, 2014). 


\section{Green Supply Chain Practices and Firm's Performance}

As stated by Rahman, Ho and Rusli (2014) firm' s performance represents a direct impact of green practices on basic outcome of measurements of firms in terms of market and financial aspects together with the customer satisfaction. However they found that only green purchasing and internal environmental practices predict the market and financial performance among manufacturers in Malaysia. Further the most cited out come in GSCP is cost reduction (Eltayeb, Zailani \& Ramayah, 2010) and improvements in financial performance (Mollenkopf \& Closs, 2005). Sarkis (2003), mentioned that there are strong relationship between GSCP and performance in economically and financially.

Financial performance is typically most important driver for adopting GSCP (Zhu, Geng, Fujita \& Hashimoto, 2010). They found that Japanese manufacturers have significantly reduced environmental costs, especially for material purchasing and fines due to environmental accidents. In China, no significant financial benefits have been gained through GSCM. However Bowen, Cousins, Lamming and Farukt (2001) stated that environmental practices don't typically result in short-term financial benefits, but long-term financial performance can be achieved. When looking at South Asian countries, lot of studies can be seen in relation to GSCP and financial performance. However the available studies are encouraging scholars to do further research on that due to differences in contexts the studies are carrying out. Compared to other South Asian countries, Sri Lanka is the country where the least studies were done in this area. Therefore this study fills the gap in terms of context base as well as knowledge base in GSCM.

\section{Methodology}

\section{Conceptual Framework}

Sarkis and Cordeiro (2001) found that internal environmental management system may assist firms in reducing their environmental impact throughout the supply chain. It requires conducting internal environmental auditing to reduce energy use and emissions of distribution activities, improving organizational performance through resource efficiencies, support from top management and total quality management. Therefore it is expected that internal environment management influences financial performance measured by Return on Equity indirectly. 
Green Purchasing is an important element in GSCM strategy. It involves selecting environment friendly suppliers and other raw materials. Initially green purchasing can be costly since the environmental friendly suppliers charge high prices than those who are not comparatively environment friendly. However it can help companies to achieve long term benefits through protecting their brand value (Sheth \& Sharma, 1997). Thus it is hypothesized that green purchasing influence Return on Equity.

Esty and Winston (2009) reveal the link between Customer Cooperation \& Eco design practices to performance measures. They found that customers lower their environmental footprint and related costs-benefits that justified price premiums, drove increased market share, and strengthened customer loyalty. Therefore the third hypothesis is created based on that.

According to Zhu at al. (2010), Investment recovery includes sale of excess inventories/materials, sale of scrap and used materials, sale of excess capital equipment. This primarily focus ison return of recyclable or reusable products and materials into the forward supply chain. Thus it is expected that Investment Recovery influences Return on Equity.

Based on the theoretical background found in the literature, research framework is conceptualized as shown in figure 1. In order to identify the relationship between green supply chain practices and financial performance, number of variables are employed that were theoretically and empirically investigated by the previous studies. Accordingly green supply chain practices are categorized in to four basic practices as internal environmental management, green purchasing, customer cooperation with environmental considerations \& eco design, and investment recovery (Zhu at al., 2010). Financial performance is measured by using Return on Equity (ROE).

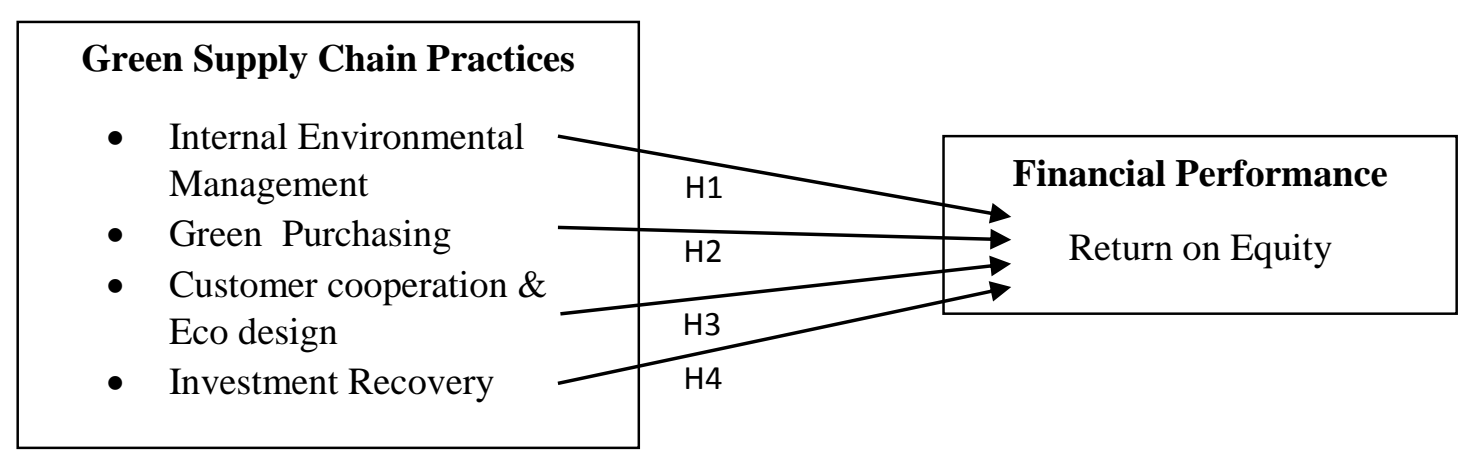

Fig. 1: Research Framework 
The study tests four hypothesis stemming from the above research framework as given below. $\mathrm{H}_{1}$-Internal Environmental Management influences Return on Equity $\mathrm{H}_{2}$ - Green Purchasing influences Return on Equity $\mathrm{H}_{3}$ - Customer Cooperation \& Eco design influences Return on Equity $\mathrm{H}_{4}$ - Investment Recovery influences Return on Equity

Structured questionnaire was used to collect data pertaining to the green supply chain practices of 25 manufacturing companies listed in Colombo Stock Exchange, Sri Lanka. Respondents were the middle level functional managers in production and supply chain areas of the company. Financial performance data of the same companies were collected from published annual reports. Study was conducted during 2015/16.

The main analytical method employed in the study is Partial Least Square Structural Equation Modeling (PLS-SEM). PLS-SEM was selected as the study has a small sample size. PLS-SEM works efficiently with small sample sizes and complex models and makes practically no assumptions about the underlying data (Hair, Hult, Ringle \& Sarstedt, 2014; Ringle, Sarstedt \& Hair, 2013).

\section{Results of Structural Equation Modelling}

PLS-SEM was performed using Smart PLS version 3.2.3 software. Each green supply chain practice; IEM, GP, CC \& RR was regressed against Return on Equity. Initial structural model had 19 indicators under four green supply chain practices as presented in figure 02.

Loadings of the initial model was checked and indicators with loadings below 0.5 is removed (Churchill, 1979). Accordingly the final structural model consists with three indicators for IEM, four indicators of CC, two indicators of IR and all five indicators of GP. Figure 03 shows the final structural model used for hypotheses testing. Internal consistency of each practice was measured using cronbach's Alpha. Accordingly each latent variable records a value above 0.7 as presented in table 01 . 


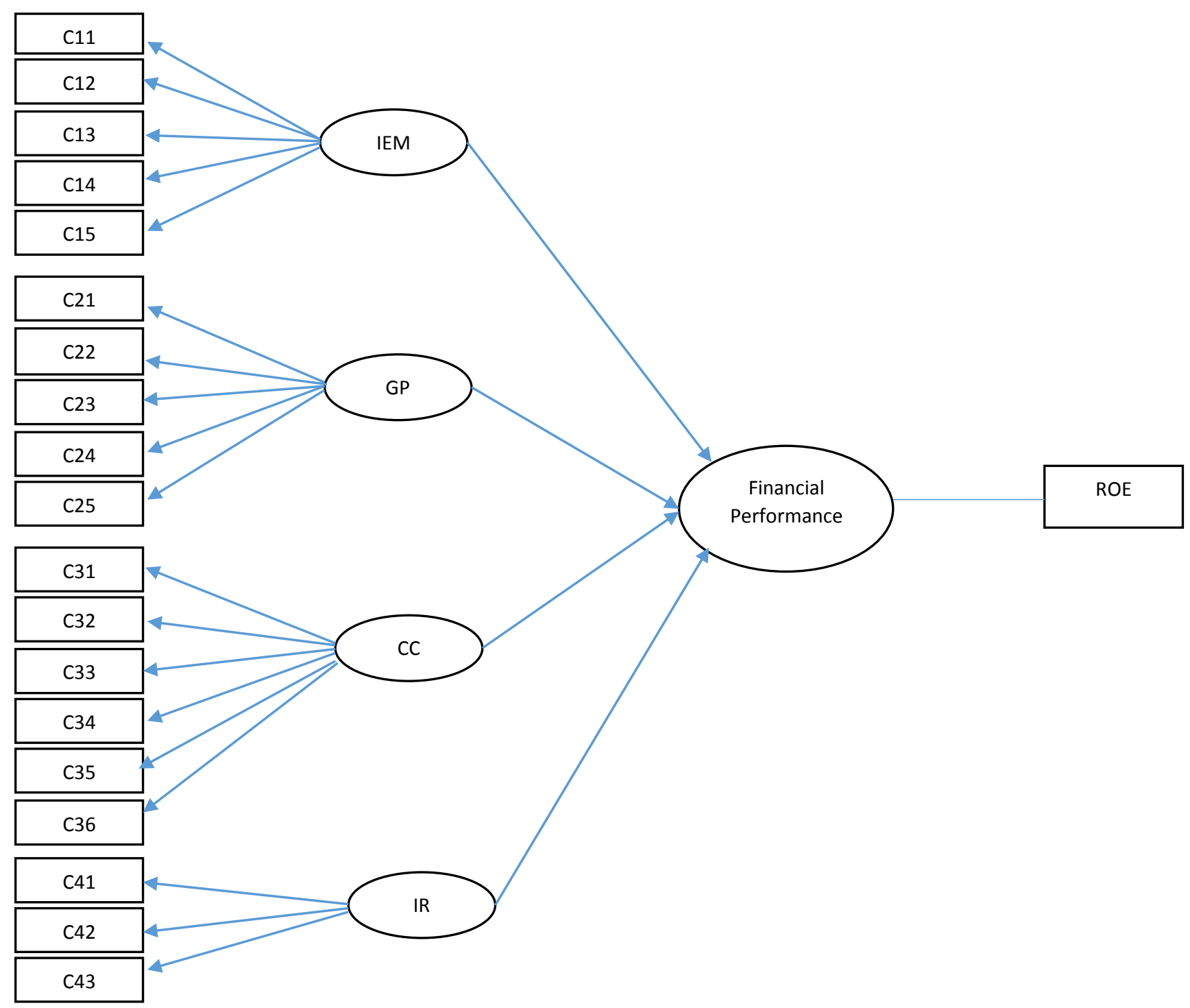

Fig. 2: Initial Structural Model

Composite Reliability of each construct ranges from 0.7 to 0.9 therefore meeting the minimum requirement of 0.7. AVE is above the minimum requirement of 0.5 (Hair et al., 2012), except the customer cooperation construct thus indicating convergent validity. However "AVE is a more conservative measure than $\mathrm{CR}$. On the basis of $\mathrm{CR}$ alone, the researcher may conclude that the convergent validity of the construct is adequate, even though more than $50 \%$ of the variance is due to error" (Malhotra \& Dash, 2011, p.702). Henseler, Ringle and Sarstedt (2015) suggests Heterotrait-Monotrait Ratio (HTMT) to test the discriminant validity of constructs. Accordingly HTMT for each fair of constructs are less than 0.9 suggeting discriminanent validity. 
Table.1: Reliability, Convergent Validity and Multicollinearity

\begin{tabular}{lcccc}
\hline \multicolumn{1}{c}{$\begin{array}{c}\text { Green Supply } \\
\text { Chain Practice }\end{array}$} & $\begin{array}{c}\text { Cronbach's } \\
\text { Aplha }\end{array}$ & $\begin{array}{c}\text { Composite } \\
\text { Reliability }\end{array}$ & AVE & VIF \\
\hline $\begin{array}{l}\text { Internal } \\
\text { Environment }\end{array}$ & 0.721 & 0.827 & 0.618 & 1.551 \\
Management & & & & \\
\hline Green Purchasing & 0.871 & 0.899 & 0.647 & 1.900 \\
\hline Customer & 0.884 & 0.689 & 0.418 & 1.612 \\
Cooperation & & & & \\
\hline Investment Recovery & 0.710 & 0.872 & 0.773 & 1.302 \\
\hline
\end{tabular}

Source: Research Data

Table.2: Discriminant Validity

\begin{tabular}{lr}
\hline Constructs & \multicolumn{1}{c}{ HTMT } \\
\hline ROE ->CC & 0.051 \\
\hline GP ->CC & 0.622 \\
\hline GP -> ROE & 0.256 \\
\hline IEM ->CC & 0.503 \\
\hline IEM->GP & 0.565 \\
\hline IR->CC & 0.247 \\
\hline IR->ROE & 0.463 \\
\hline IR->GP & 0.238 \\
\hline IR->IEM & 0.408 \\
\hline \multicolumn{2}{c}{ Source: Research Data }
\end{tabular}

Having confirmed the reliability and validity of constructs, multicollinearity also tested using Variance Inflation Factor (VIF) and accordingly it is less than the threshold of 10 as presented in table 01 . Thus variables do not have multicollinearity problem. 


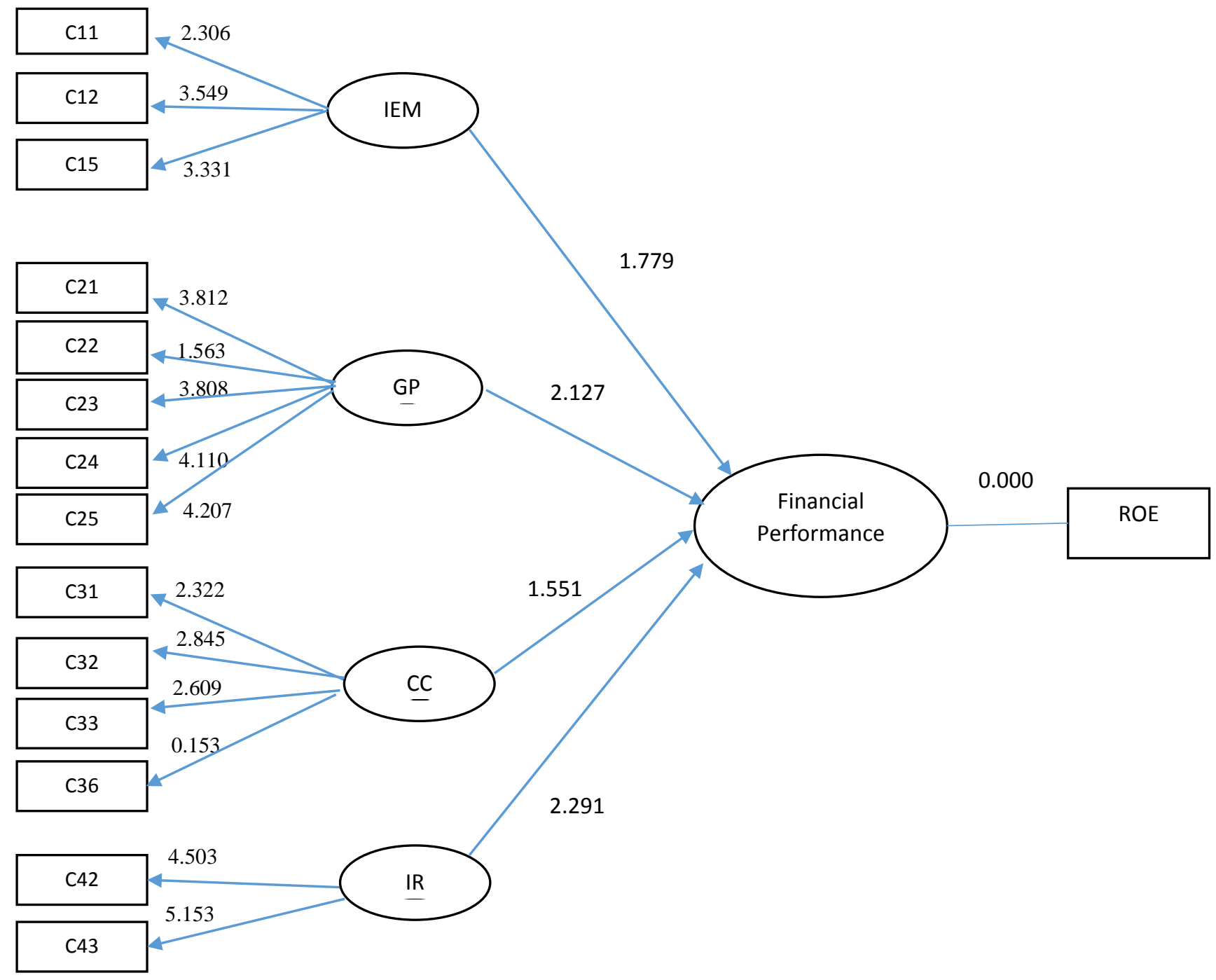

Fig. 3: Final Structural Model

Hypotheses were tested using bootstrapping option for 5000 samples (Hair et al., 2014). The results of the regression are presented in table 03.

Table 3: Regression Results

\begin{tabular}{llllll}
\hline Hypotheses & $\begin{array}{l}\text { Hypotheses } \\
\text { path }\end{array}$ & $\begin{array}{l}\text { Path } \\
\text { Coefficients }\end{array}$ & T-Values & P-Value & Accept/Reject \\
\hline H1 & IEM $\rightarrow$ ROE & 0.470 & 1.779 & 0.075 & Reject \\
\hline H2 & GP $\rightarrow$ ROE & -0.569 & 2.127 & 0.033 & Accept \\
\hline H3 & CC $\rightarrow$ ROE & 0.404 & 1.551 & 0.121 & Reject \\
\hline H4 & IR $\rightarrow$ ROE & -0.429 & 2.291 & 0.022 & Accept \\
\hline
\end{tabular}

Source: Research Data 
Analysis of significance shows that green purchasing and investment recovery significantly influence financial performance as measured by ROE. However the other two green supply management practices i.e internal environment management and customer cooperation do not significantly affect ROE. Moreover both green purchasing and investment recovery practices negatively affect the financial performance. This suggests that efforts on green purchasing and investoment recovery practices reduces the financial performance of the company.

\section{Discussion and Conclusion}

Literature provides mix results as to the impact of green supply chain practices on financial performance. The current study conducts in the Sri Lankan context provides evidences for the impact of certain green supply chain practices on the financial performance. More specifically the green purchasing and investment recovery practices significantly influence on firm financial performance. However these two practices are negatively associated with financial performance and it is contradicted to the findings of Zhu and Sarkis (2007).

According to Zhu and Sarkis (2007), Green purchasing positively influence to the financial performance. As they further explained, Green purchasing requires less time for additional worker training and less need for supporting technologies, thus it is less costly to implement green purchasing among manufacturers in China. Therefore they do not expect that Green purchasing detriment economic performance. However in Sri Lanka, Green purchasing practices generally add extra costs to the firm as most of firms are not at the mature stage of practicing GSCM. Thus resulting decrease in short term profits.

Zhu and Sarkis (2007) found that Investment Recovery positively impacts economic performance under conditions of regulatory and competitive pressures but not market pressure. We generally found that the opposite for Sri Lankan sample. Investment recovery has not gained much attention in Sri Lankan manufacturers than other countries like China and USA. These contradictory results may be explained by the differences in the context.

Based on the above results and discussion, it can be concluded that reason for contradict results of Green supply chain practices on financial performance may be, Sri Lankan manufacturers are still at the early stage for the implementation of GSCM practices due to lacking experience, technology and infrastructure compared to other developed countries and there is no strong pressures from market, customers and the regulatory body to implement it. 


\section{References}

Bowen, F., Cousins, P., Lamming, R., \& Farukt, A. (2001). The Role of Supply Management capabilities in Green Supply. Production and Operations Management, 174-189. https://doi.org/10.1111/j.1937-5956.2001.tb00077.x

Chang, B. Y., Kenzhekhanuly, Y., \& Park, B. (2013). A Study on Determinants of Green Supply Chain Management Practice. International Journal of Control and Automation, 6(3).

Churchill, G. (1979). A paradigm for developing better measures of marketing. Journal of Marketing Research, 16(1), 64-73. https://doi.org/10.2307/3150876

DiMaggio , P., \& Powell, W. (1983). The iron cage revisited: institutional isomorphism and collective rationality in organizational fields. American Sociological Review, 147-160. https://doi.org/10.2307/2095101

Eltayeb, T., Zailani, S., \& Ramayah, T. (2010). Green Supply Chain Initiatives among Certified Companies in Malaysia and Environmental Sustainability: Investigating the Outcomes. Resource, Conservation and Recycling, 495-506.

Esty, D.C. and Winston, A.S. (2009), Green to Gold: How Smart Companies Use Environmental Strategy to Innovate, Create Value, and Build a Competitive Advantage, rev. and updated ed., Wiley, Chichester and Hoboken, NJ.

Gilbert, S. (2000). Greening Supply Chain: Enhancing Competitiveness Through Green Productivity. Republic of China : Asian Productivity Organization.

Hair, J. F., Sarstedt, M., Ringle, C. M., \& Mena, J. A. (2012). An assessment of the use of partial least squares structural equation modeling in marketing research. Journal of the Academy of Marketing Science, 40(3), 414-433. https://doi.org/10.1007/s11747-011-0261-6

Hair, J. F., Hult, G. T., Ringle, C. M., \& Sarstedt, M. (2014). A primer on partial least squares structural equation modeling (PLS-SEM). Thousan Oaks: Sage.

Hart, S. L., \& Ahuja, G. (1996). Does it Pay to Be Green? An Empirical Examination of the Relationship between Emission Reduction and Firm Performance. Business Strategy and the Environment, 5(1), 30-37. https://doi.org/10.1002/(SICI)10990836(199603)5:1<30::AID-BSE38>3.0.CO;2-Q 
Henseler, J., Ringle, C. M., \& Sarstedt, M. (2015). A New Criterion for Assessing Discriminant Validity in Variance-based Structural Equation Modeling. Journal of the Academy of Marketing Science, 43(1), 115-135. https://doi.org/10.1007/s11747-014-0403-8

Hiroki, I., \& Keisuke, O. (2010). How Does Environmental Performance Affect Financial Performance? Evidence from Japanese Manufacturing Firms. Munich Personal RePEc Archive, No 27771.

Klingenberg, B., \& Geurts , T. (2009). A Theoretical Framework For Financial Performance Measurement Of Operations Management Strategies. In Proceedings of the Northeast Decision Sciences Institute. Smithfield, RI,: Northeast Decision Sciences Institute.

Malhotra, N. K., \& Dash, S. (2011). Marketing research: an applied orientation. New Delhi: Pearson Publication.

Mollenkopf, D., \& Closs, D. (2005). The hidden value in reverse logistics. Supply Chain Management Review, 34-43.

Narasimhan, R., \& Carter, J. R. (1998). Environmental supply chain management. Center for Advanced Purchasing Studies.

Ngniatedema, T., \& Li, S. (2014). Green Operations and Organizational Performance. International Journal of Business and Social Science, 5(3). Retrieved from www.ijbssnet.com

Rahman, A. A., Ho, J. A., \& Rusli, K. A. (2014). Pressures, Green Supply Chain Management Practices and Performance of ISO 14001 Certified Manufacturers in Malaysia. International Journal of Economics and Management, 8, 1-24.

Ringle, C., Sarstedt, M., \& Hair, J. F. (2013). Partial least squares structural equation modeling: Rigorous applications, better results and higher acceptance. Journal of Long Range Planning, 46(1), 1-12.

Sarkis, J., \& Cordeiro, J. (2001). An Empirical Evaluation of Environmental Efficiencies and Firm Performance: Pollution Prevention versus End-of-Pipe Practice. European Journal of Operational Research, 135(1), 102-113. https://doi.org/10.1016/S0377-2217(00)00306-4

Sheth, J.N. and Sharma, A. (1997), "Supplier relationships: emerging issues and challenges", Industrial Marketing Management, Vol. 26 No. 2, pp. 91-100 https://doi.org/10.1016/S0019-8501(96)00153-8 
Shi, V. G., Koh, S., Baldwin, J., \& Cucchiella, F. (2012). Natural resource based green supply chain management. Supply Chain Management: An International Journal, 17(1), 54-67. https://doi.org/10.1108/13598541211212203

Sarkis, J. (2003). A strategic decision framework for green supply chain management. Journal of cleaner production, 11(4), 397-409. https://doi.org/10.1016/S0959-6526(02)00062-8

Shultz, C., \& Holbrook, M. (1999). Marketing and the Tragedy of the Commons: A Synthesis, Commentary, and Analysis for Action. Journal of Public Policy \& Marketing, 18(2), 218229.

Slack, N., Jones, A. B., Johnston, R., \& Betts, A. (2012). Operations and Process Management with eText: Principles and Practice for Strategic Impact (3rd ed.). United Kingdom: Pearson.

Slywotzky, A., Morrison, D., \& Weber, K. (2000). How Digital Is Your Business? Management Journal, 729-753.

Srivastava, S. K. (2007). Green supply-chain management: A state-of-the-art literature review. International Journal of Management Reviews, 53-80. https://doi.org/10.1111/j.1468$\underline{\text { 2370.2007.00202.x }}$

Zhu, Q., \& Sarkis, J. (2004). Relationships between operational practices and performance among early adopters of green supply chain management practices in Chinese manufacturing enterprises. Journal of Operations Management, 265-289. https://doi.org/10.1016/j.jom.2004.01.005

Zhu, Q., \& Sarkis, J. (2007). The moderating effects of institutional pressures on emergent green supply chain practices and performance. International Journal of Production Research, 45(18-19), 4333-4355. https://doi.org/10.1080/00207540701440345

Zhu, Q., Geng, Y., Fujita, T., \& Hashimoto, S. (2010). Green supply chain management in leading manufacturers: Case studies in Japanese large companies. Management Research Review, 33(4), 380-392. https://doi.org/10.1108/01409171011030471 